\title{
Semar puppet counseling model
}

\author{
Bakhrudin All Habsy ${ }^{*}$ \\ Universitas Negeri Malang \\ *) Corresponding author, $\doteq$ e-mail:bakhrudin_bk@yahoo.com
}

\begin{abstract}
Puppet as the original local wisdom has a great role in the character building and giving a good example of how to behave, puppet is also the source or guidance of how to behave well. One of the figures in puppet that has strong characteristic as the leader, protector, patron, and also the guide for ksatria in taking the decision is Semar. Semar has the perfection ethic of Javanese person and raise as the core of the soul of Javanese people. Semar's wisdom can be applied in the development of multi culture Counseling for Counselor and multi culture Counseling characteristic. The characteristic of multi cultural based Counselor are: (1) Prudent, (2) Helper, (3) Motivator, (4) Democratic, (5) Fair, (6)Associating, (7) Sustains on the objectives, (8) Responsible, (9) Teaching, (10) Wholeheartedly, (11) Well mannered, (12) Sincere, (13) Honest, (14) Faithful, (15) Unpretentious (16) Not an anti critical, (17) Able to keep secret, and (18) Positive thinking. The application of Counseling based on the Semar's characters is offered to develop the practice of multi cultural Counseling for the Counselors, it called puppet semar counseling model.
\end{abstract}

Keywords: Counseling model, semar puppet, multi cultural counseling

How to Cite: Hasby, B.A. (2017). Semar puppet counseling model. Couns-Edu: International Journal of Counseling and Education, 2(1): pp. 19-24. DOI: 10.23916/002017024410

\section{Introduction}

The civilization, especially the civilization of Indonesian people has been developing through culture. Based on Kluckhohn and Kelly, culture is every form of life that has been created historically, written or implied, rationale or irrational in a certain period of time as the potential guidance for human being. Corey (2010) stated that a complex culture has a philosophical basis and a self thought in many ways, and in this case is counseling approach. One of the Javanese culture that seems to be soul of the Javanese philosophy is Puppet (wayang).

Based on Achmadi (2003) Puppet (wayang) is "wawayanganing manungso"which means puppet is the symbol of life and human living, by understanding Puppet we will be able to live our life better. UNESCO (The United Nations Educational Scientific and Cultural Organization) at 7 December 2003 in Paris has decided Puppet as the Masterpiece of The Oral and Intangible of Humanity (adiluhung). It shows that puppet as the one of the traditional culture has be acknowledged internationally as a value of the formation and development of Indonesia national identity.

Mulyono (1983) stated that Puppet as the symbol of the language of life which is tent to be more spiritual. Puppet is the symbol that explains the existence of human in relation with the natural and supernatural thing. Puppet also has a strong relation with social life, culture, and the religious of Javanese people, for examples Punakawan are always become the favourite in every puppet show, the Punakawan 
represents the most people and they are the guides for warrior (ksatria). In Javanese puppetry, there is term called sedulur papat limo pancer that represents ksatria and their servant. Sedulur papat are Punokawan (Semar, Gareng, Petruk, and Bagong), limo pancer are Pandawa Lima (kstaria), they are: Yudistira, Arjuna, Bima, Nakula and Sadewa. Based on the Javanese spiritual, Semar represents sukma (soul), and Pandawa Lima represents body that tend to be careless weak, and the body needs soul to be stable. It must be nartured by the bodies great teacher or leader (pamong agung) to keep remember and alert (eling lan waspodo).

Based on Guritno (1976), punokawan represents human characteristics, Semar represents Karsa (Intention), Gareng represents Cipta (mind, thought), Petruk represents Rasa (feeling), and Bagong represents Karya (action). From those four figures, Semar is the role model. Semar, sometimes also called Ki Lurah Semar also known as great teacher or leader (pamong agung) or Kyai Semar, is also a great teacher or leader for others. Semar represents a tutor and also a leader, a guide of physical and spiritual of all ksatria. Semar also considered as God's revelation (terang ilahi) to establish a good moral (welas asih, gotong royong), merciful, and people oriented.

Krisna (2012) stated that Semar is comes from the word ismar which means nail, he is the one who make the truth stronger, just like nail. Semar is an unpretentious, calm, humble, genius, and knowledgeable. Semar has wise advices and also become a role model for others. Based on Hermawan (2013) in Javanese tradition semar has an alias, it called Badranaya, it comes from the word bebadra which means establishing the medium and naya/nayaka which means messenger, so semar also considerd as a messenger of God to bring peace for human. Christanto (2013), Semar leads and give guidance to ksatria. The guidance is the wise advices and the action and it prevents ksatria from doing bad things.

The great values of Semar can be actualized in daily life, those are cipta, rasa, and karsa. Cipta is the power to create the image in our mind about life. Rasa is the soft feeling of ourselves and very often it gives us an impression. Karsa is the trigger of Cipta and Rasa, Karsa makes Cipta and Karsa become true.

The understanding of human psychological aspects will determine them into psychologically healthy or not. Based on Corey (2010: 213) the perspective of basic human characteristics is important for therapeutic action. From many psychological theories around the globe, each of it can give the contribution to counselor to give the best treatment.

Based on that, it needs to conduct the research about the values of Semar in the application of counseling by the counselor. The objective of such research is the value of Semar contains ethics, life perspective, tradition, philosophy, which can be used in this heterogeneous country. According to Pedersen (1991), the approach of multi cultural can be seen as the fourth aspects in counseling after psychodynamic, behavioristic, and humanistic. Counseling practice should be in line with the Indonesian culture. Collins and Arthur (2007: 31-49) stated that the counselors should aware their own culture, and it is in line with Wolfgang et al (2011: 1-16), the counselor should be able to internalize the local culture in their counseling.

Semar is the figure that has the same characteristics with today's educator, who responsible to educate people to become the one who have integrity, smart, humble, helping each other (Kresna, 2010: 67). Semar's value supposed to be a new counseling model, in order to prevent the cultural reduction and it is suitable with the Indonesia culture.

\section{The counselor personality in counseling practice based on the value of semar}

Based on Atkinson, Morten and Sue (1989), a multi cultural Counseling is the relation between a Counselor and his client in different ways such as: sex, sexual orientation, socio economics factors, and age. Based on the explanation of multi cultural Counseling, it can be said that the model of Counseling in Indonesia is based on western model, especially United States, and this western model gives different result.

Indonesian culture which is in the same way is an eastern culture considers teacher and also Counselor as the one who have the same position as parents. Parents are also has a very significant role in building the characters. In Javanese Culture, the obedience of children to their parents is very precious, a good child is the one who obey (manut) to their parents, and the one who does not obey their parents is not a good child. It is different in the United States; there the counseling is about the same situation between the 
Counselor and their Client (konseli). A Counselor in Indonesia should have a strong characteristic and authority, even his role is a problem solver and a facilitator. This cultural barrier can emerge the reluctant of the client to take a spontaneous action if facing the Counselor individually. Clients (konseli) are hoped to be more spontaneous in a multicultural nuance.

Based on Nasution (2009), Semar has discipline, religious, and a warm feeling. Based on the textual concepts, Semar has values that can be applied in a multicultural Counseling process:

\section{Prudent}

Semar is smart, but in the other hand, he is the wisest figure. He is knowledgeable, and he is very powerful before Arjuna, even Semar is just servant (batur). Because of his knowledge and wisdom, he becomes a very significant figure before god, and his opinion is accepted by god. When Bathara Guru do something wrong, only Semar who are brave to correct him. Semar is also the one who can do action based on where he stands in every situation. A Counselor should be wise in understanding himself, someone else, and the situation.

\section{Helper}

Semar very often helps ksatria, their students. As a Counselor, they should be also become a helper for their clients. Very often, Semar warn ksatria about the danger that has not come yet. When the bendera is in the hard situation, Semar is able to cheer him with his wise advice. In Begawan Kilat Buwana, when Pandawa is in a deadly situation by Kurawa, Semar helped them by removing Begawan Kilat Buwana. A counselor helps the client to solve the problem, help them to reduce one by one of their client's problem.

\section{Motivator}

Semar is always become a motivator for the ksatria to be the real ksatria. Semar motivates them to be stronger day by day and nothing to lose. In line with the Counselor, he should be able to motive their client to take responsible of what they do to solve the problem.

\section{Democratic}

Semar never push the ksatria to totally obey him. A Counselor is hoped to not to push the client to totally obey their advice too. A Counselor may not give a personal judgment to their client based on their perspective.

\section{Fair}

Semar has friend from many elements in jongring saloka, such as ordinary people, government officer, and even god. In Semar Kuning story, Semar came in the form of human with fairness, honest, togetherness, and always say the truth. A Counselor should be fair in giving a Counseling without asking clients background.

\section{Associating}

Semar is always available when ksatria has no one to guide. Semar become a connector and balance maker between god and human in social and political life. A Counselor applied this to his client to make them grow better.

\section{Sustains on the objectives}

Semar has role in keeping, caring, guiding, and giving solution toward the problem of his clients. Semar are always guiding ksatria to finish their job well. A Counselor applies the sustainable Counseling to the clients, so that the problem of the client will be totally solved. 


\section{Responsible}

Semar tries to build a mental and the characteristics of all ksatria so that they are responsible of what they do. A Counselor take this value to the clients so that the client will e responsible with their problem.

\section{Teaching}

In the story entitled Semar Boyong, Semar teaches and told the ksatria that Punokawan will leave them if they act beyond the truth. In Counseling process, a Counselor teaches the client to be better, understanding their selves, take the decision and responsible of what they do.

\section{Wholeheartedly}

In Ladrang Clunthang story, Punokwan totally give very wise wisdom to the ksatria dealing with their safety. A Counseling process should be done in a professional framework. A Counselor has commitment that becomes basis in helping the client.

\section{Well mannered}

His well mannered behavior makes Semar very significant figure. His advice is always become a second opinion in taking the decision. A Counselor should behave well before the clients so that they will not think twice in delivering their problems.

\section{Sincere}

Semar is known as the helpful person, but he does not hope for the reply. It should also be applied by the Counselor, they may not hope for the reply from the Counseling they give.

\section{Honest}

In Semar Kuning story, Semar do many good things without any special intention. Semar represents honesty, simple, and even he is just a servant, but he also becomes teacher or parents for ksatria. It means he also has the responsibility to show the right way to the all ksatria. A Counselor should be able to become the one who has integrity, intelligence, honest, patience, and consistence.

\section{Faithful}

The faith and the integrity of Semar is unlimited. Semar, with all Punokawan make ksatria become stronger and better. Semar is honest, and this good character makes ksatria always obey Semar even he is just a servant. As a Counselor, we have to build a good relationship with the client with harmony, dynamic, and creative.

\section{Unpretentious}

When he come the world, he come with honesty, but actually Semar is a undefeatable god. He is always humble even he can solve the problem. A Counselor should be able to conclude the client's problem in the simple word so that the client will understand.

\section{Not an anti critical}

Semar has all the characters the Indonesian people needs, it is able to accept critical and in other side keeping the secret. A Counselor should be able to correct their selves and is able to accept the critical.

\section{Able to keep secret}

Semar is also comes from the word samar which means in the "grey area". Semar has the capability to momong and momot, momong means educate and momot means is able to keep the secrets. A Counselor should keep his clients secrets and data. 


\section{Positive thinking}

In communicating, Semar is always gives the positive perspective. His speech is mostly about giving advices. We as the Counselor must always give the positive thing to our clients.

\section{Semar puppet counseling model}

Counseling is the part of integrated Counseling model in school, and it is also an integrated program by the professional Counselor. One of the skills that must be mastered by the Counselor is the multicultural based Counseling. The knowledge and the mastery of multicultural Counseling will be very useful to give the Counseling in Indonesia for general, especially in region.

Ivey (2011) stated that the main competency that must be mastered by the Counselor is multicultural based Counseling, this mastery will result a good condition in Counseling process. The knowledge of multicultural in Counseling process is very useful because culture is the basis of a country (Matsumoto \& Juang, 2003). Erford (2010) the knowledge of multicultural will add the recommendation in Counseling process.

Semar Puppet Counseling model was developed by concerning to the cultural based Counseling that is universally right. Semar Puppet is offered to the development of multicultural Counseling practice. There is a perspective that the good result of Counseling is based on the Counselor who is concerned on the client's culture.

Semar Puppet Counseling sees human based on the sedulur papat limo pancer concept. In every of us, there is soul and body, soul is the educator of our body, because body is too weak in making decision. Human life is based on the value of humanity itself, we are not a human is a wolf for other human (homo homini lupus).

Human has three characteristics; those are cipto, roso, and karso. Cipto is the power to create the image in our mind about life. Roso is the soft feeling of ourselves and very often it gives us an impression. Karso is the trigger of Cipto and Roso, Karso makes Cipto and Karso become true.

The objectives of Semar Puppet Counseling is to help clients to be closer to God, to get Mahabbah/ holy love (asmarasanta), as the medium of thinking that influence the soul. After diagnosed the problem, the next step is identifying that gained from: (1) Jamus Kalimosodo, (2) Sedulur Papat Limo Pancer Gospel (3) Reflective Dialogue (4) Pancawisaya Gospel, that is used to catch five things, they are: Rogarda, Sangsararda, Wirangharda, Cuwarda and Durgarda.

The step of Semar puppet Counseling are: (1) Beginning, the assessment that is done to analyze the emotion, (2) Working process giving treatment to the cognitive aspect which is the central aspect of intervention in Semar puppet Counseling that is simultaneously bring the influence in desire and emotion, using the relevance technique, and (3) Last step, The Counseling process may be finished if the clients has beyond the truth.

\section{Conclusions}

Semar has values that can be applied in a multicultural Counseling. The application of Counseling based on the Semar's characters is offered to develop the practice of multi cultural counseling for the Counselors, it called puppet semar counseling model.

\section{Acknowledgments}

I would like to thanks to Prof Dr Nur Hidayah, M.Pd and Prof Dr Andi Mappiare for being a role model and an inspiration as supervisor. However special who have commented on the technique of writing articles that he wrote for the better manuscript 


\section{References}

Achmadi Amsoro. (2003). Filsafat dan Kebudayaan Jawa. Upaya Membangun Keselarasan Islam dan Budaya Jawa. Semarang: Cendrawasih.

Asosiasi Bimbingan dan Konseling Indonesia. (2007). Rambu-Rambu Penyelenggaraan Bimbingan dan Konseling dalam JalurPendidikan Formal (NaskahA kademik). Bandung: ABKIN.

ASCA. (2005). "The ASCA National Model: A Framework for School Counseling Programs". Michigan: The American School Counselor Association.

Corey, G. (2010). Theory and Practice of Counseling and Psychotherapy. Belmont, CA: Brooks/Cole.

Christianto, W.N. (2003). Peran dan Fungsi Tokoh Semar Bagong Dalam Pagelaran Lakon Wayang Kulit Gaya JawaTimuran. Jurnal Humaniora, 15, 285-301.

Collins, S \& Arthur, N. (2007). A Framework for Enhancing Multicultural Counseling Competence. Canadian Journal of Counseling, 41 (1): 31-49.

Erford. T Bradley \& Danica G. Hays. (2010). Developing Multicultural Counseling Competence Counselor: A systems approuch. 2nd Edition. USA: Pearson.

Firmanto, D. (2012). EpistemologiPunakawan. Yogyakarta PaguyupanWayang.

Gibson, R.L \& Mitchell, M.H. (2011). Bimbingan dan Konseling. Yogyakarta. PustakaPelajar.

Guritno. (1985). Lordly Shades; Wayang Purwa Indonesia. Jakarta: Published Through the Genorosty of Bapak Probosoetedjo.

Hermawan Deny. (2003). Semar dan Kentut Kesayangannya. Yogyakarta Diva Press.

Hepner, P. P., Wampold, B.E., \& Kivlinghan, D. M. (2008). Research Desain in Counseling (3rd ed.). California: Thomson Brooks/Cole.

Ivey, E Allen. (2011). In the Special Issue on Multicultural Social Justice Leadership Development. Guest Editor: Carlos P. Zalaquett, University of South Florida.

Krisna Andrian. (2012). Dunia Semar. Abdi Sekaligus Penguasa Sepanjang Zaman. Yogyakarta Diva Press.

Matsumoto, D \&Juang, L. (2003). Culture and Psychology. $2^{\text {nd }}$ Edition. Belmont, CA: Wadsworth.

Mulyono, S. (1983). Apa dan Siapa Semar. Jakarta: CV Haji Masahung MCMLXXXII.

Mulyono, S. (1978). Wayang Asal Usul, Filsafat dan Masa Depannya. CV Haji Masahung.

Morten, G., \& Sue, D.W. (1989). Counseling American Minorities: A cross-cultural perspective. Dubuque, IA: Brown.

Nasution, M.I. (2009). "Semar Gugat" dalam Telaah Tokoh: Sebuah Model Pemaknaan Naskah Drama. Journal State University of Padang.

Nelson-Jones, R. (2011). Teori dan Praktik Konseling dan Terapi, Edisi Keempat. Terjemahan Soetjipto, P.H \& Soetjipto, M.S. 2011. Yogyakarta: Pustaka Pelajar.

Pedersen.C.H. (1991). Multicultural Counseling: from diversity to Universality. Journal of Counseling and Development.

Purwadi. (2014). Mengakaji Nilai-Nilai Luhur Tokoh Semar. Karwa Publisher Yogyakarta.

Wolfgang, J., Frazier, K., West-Olatunji, C., Barrett, J. (2011). Developing Cross Cultural Competence: Applying Development and Prevention Ideals to Counseling Young Children. ERIC Institute of Educatioan Sciences. 